\title{
The Composite Supercapacitor
}

Richard Fields ${ }^{\mathrm{a}}$, Dr. Chunhong Lei ${ }^{\mathrm{a}}$, Dr. Foivos Markoulidis ${ }^{\mathrm{a}}$, Dr. Constantina Lekakou ${ }^{\mathrm{a}, *}$

aDepartment of Mechanical Engineering Sciences, University of Surrey, Guildford, Surrey GU2 7XH, UK

*Corresponding author's email: C.Lekakou@surrey.ac.uk

*Tel: $0044(0) 1483689622$ 


\section{GRAPHICAL ABSTRACT FOR THE TABLE OF CONTENTS}

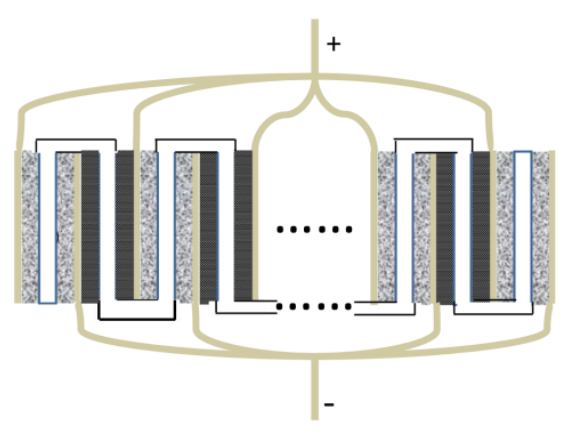

Inspired by the design of composite materials, a novel composite supercapacitor is proposed, designed and tested, comprising an integrated cell with high power- and high energy-related electrode

materials. The application-specific composite supercapacitors offered a weight reduction of $40-60 \%$ compared to same performance supercapacitors based on the high power or on the high energy-related electrode material only. 


\begin{abstract}
Inspired by the design of composite materials, a novel composite supercapacitor is proposed comprising an integrated cell with high power- and high energy-related electrode materials so that the composite electrochemical double layer capacitor (EDLC) is the equivalent circuit of a high power EDLC of power $\mathrm{P}_{1}$ and energy $\mathrm{E}_{1}$ and a high energy EDLC of power $\mathrm{P}_{2}$ and energy $\mathrm{E}_{2}$ connected in parallel. A methodology is proposed and validated in this study for the design of an application-specific composite supercapacitor of power $\mathrm{P}$ and energy $\mathrm{E}$, where $\mathrm{P}_{1} / \mathrm{E}_{1}>\mathrm{P} / \mathrm{E}>\mathrm{P}_{2} / \mathrm{E}_{2}$. The methodology was tested successfully in application-specific composite supercapacitors of medium and large size, fabricated in this study in the form of pouch cell with organic electrolyte. The application-specific composite supercapacitors offered a weight reduction of $40-60 \%$ compared to same performance supercapacitors based on the high power or on the high energy-related electrode material only.
\end{abstract}

Keywords: activated carbon; electrochemistry; energy storage; power source; supercapacitor. 


\section{HIGHLIGHTS}

- A novel composite supercapacitor is proposed inspired by composite materials.

- It comprises a cell integrating high power and high energy electrodes in parallel.

- A precise methodology is proposed for the design of a composite supercapacitor.

- The design of application-specific composite supercapacitors was tested successfully.

- Application-specific composite supercapacitors offered a 40-60\% weight reduction. 


\section{INTRODUCTION}

Supercapacitors are generally of higher power density than batteries although there has been intensive research to raise also the energy density of supercapacitors ${ }^{[1]}$ so they can store more energy and discharge their high power for longer times. Typical supercapacitors are of the electrochemical double layer (EDLC) type, which operate without redox reactions; the absence of redox reactions means that a chemical reaction does not slow down the charge or discharge operation and also the EDLCs would not age as rapidly as batteries, operating for millions of cycles at high power.

Supercapacitors are used in a variety of applications which include: (a) High power pulse applications, such as the operation of a flash or of mechanical actuators in digital cameras. (b) Provision of power peaks above an approximately steady power threshold provided by the battery, in which case the supercapacitor relieves the battery from heavy duty, high current and high rates of charge or discharge, and prolongs the lifetime of the battery ${ }^{[2]}$. This can be used to include start-stop systems with energy regenerative braking for electric vehicles (EVs) and hybrid electric vehicles (HEVs). Another application of battery-supercapacitor systems along these principles is fast acting short term power back up for UPS (uninterruptible power supply) applications ${ }^{[3]}$. (c) Smoothing short-term power fluctuations in the grid due to fluctuations in demand ${ }^{[4]}$, performing power balancing during islanding mode in the grid or microgrids, and smoothing out power fluctuations in the grid or microgrid due to the operation of intermittent renewable energy sources ${ }^{[5]}$. (d) Providing transient power assistance to fuel cells which are of very low power density ${ }^{[6,7]}$.

Although supercapacitors are preferred for high power applications, different supercapacitor applications, even within the same field, have different requirements of maximum energy-to-power ratio that naturally do not always match exactly the energy-to-power ratio of existing or off-the-shelf supercapacitors. For example the different requirements for supercapacitors derived in the 
FreedomCAR-USABC programme ${ }^{[8]}$ include: a $12 \mathrm{~V}$ transient start-stop (TSS) application with an energy-to-maximum power ratio of $15 \mathrm{Wh} / 4200 \mathrm{~W}=12.9 \mathrm{~s}$; a $42 \mathrm{~V}$ start-stop (FSS) application with an energy-to-maximum power ratio of $30 \mathrm{Wh} / 6000 \mathrm{~W}=18 \mathrm{~s}$; a $42 \mathrm{~V}$ transient power assist (TPA) application with an energy-to-maximum power ratio of $60 \mathrm{Wh} / 13000 \mathrm{~W}=16.6 \mathrm{~s}$. In an example for grid applications, supercapacitor requirements in two different functions include: supercapacitors to ensure power quality with $0-5 \mathrm{~s}$ discharge and up to 1 min capacity; supercapacitors for regulation with seconds discharge and capacity.

High energy density is proportionally associated with a high specific capacitance whereas high power density is associated with low internal resistance. It has been shown that, in general, capacitance increases with pore size of electrode, but there is a much larger sudden increase of capacitance with decreasing pore size when the size of the largest electrolyte ion is equal to, or slightly larger than, the pore opening size so that the largest ion swells the pore slightly when the pore size is near the limit of being accessible by the ion ${ }^{[9]}$. Accordingly, porous active electrodes can be developed comprising large pore surface area with a micropore opening size similar to that of the size of the largest ion of the electrolyte, which maximise the capacitance and specific capacitance. Hence, the energy and energy density could also be maximised, at least at low current densities. However, if higher currents are required, the ions "jammed" in the small, slightly swollen pores of the active electrode are unable to move quickly, and so such high energy density supercapacitors are unable to deliver high current densities and do not have very high power densities. This is critical for organic and ionic liquid electrolytes, generally used in supercapacitors for medium and high voltage applications, as such electrolytes have large cation size of the order of 0.4 to $1.3 \mathrm{~nm}$ in unsolvated or solvated form ${ }^{[10]}$. In general, it has been acknowledged that granular activated carbon (AC) coatings have a large proportion of macro- and micro-pores compared to AC fabrics which have generally only micropores of size of the order of $1 \mathrm{~nm}{ }^{[11]}$. As such AC coatings 
would allow for faster ion mobility and thus high power. Further reductions in cell resistance can be achieved by using conductive additives such as carbon black ${ }^{[12-15]}$, carbon nanotubes ${ }^{[16,17]}$, graphene or graphene functionalised with iron groups to increase interplatelet conductivity ${ }^{[18]}$. Hence, depending on the relation between smallest pore size and biggest electrolyte ion size as well as the presence of fast ion motion through macro- and meso-porous paths, overall resistance of the porous active electrode and its contact resistance with the current collector, EDLC supercapacitors may be classified as high power or high energy supercapacitors. Fig.1 presents the Ragone plots of coatingbased supercapacitors (from ${ }^{[17]}$ and also based on AC powder used in the (C1) supercapacitor coating of the present study) and the Ragone plots of AC fabric-based supercapacitors (from ${ }^{[1]}$ and also the (C2) supercapacitor of the present study). It is clear that Fig.1(a) presents relatively high power density supercapacitors whereas Fig.1(b) presents relatively high energy density supercapacitors.

The novel concept of a "Composite Supercapacitor" proposed in this study has been inspired from the concept of engineering composite materials in which fibers generally offer high stiffness and high strength whereas the more flexible polymer matrix offers connectivity and toughness. Similarly, in this study we are proposing a composite supercapacitor consisting of two integrated material components, a high power EDLC-equivalent with high power active electrodes and a high energy EDLC-equivalent with high energy active electrodes. Although hybrid battery-supercapacitor devices have been reported in the literature ${ }^{[19-20]}$ with the aim of increasing the power density of batteries, the composite supercapacitor is an entirely novel idea, associated with a precise methodology to design the composite supercapacitor to be presented in this paper following rule of mixtures and inverse rule of mixtures for the composite capacitance and resistance, respectively, with both rules being widely applicable to composite materials ${ }^{[21]}$. 
The composite supercapacitor device proposed in this study contains integrated high power EDLCequivalent cells of power $\mathrm{P}_{1}$ and energy $\mathrm{E}_{1}$, and high energy EDLC-equivalent cells of power $\mathrm{P}_{2}$ and energy $E_{2}$, where $E_{2}>E_{1}$ and/or $P_{1}>P_{2}$. We are presenting a methodology to predict the required high power-related active electrode material and the required high energy-related active electrode material for an application-specific composite supercapacitor which would comply to the power/ or resistance and energy or capacitance specifications of the application of interest where it is expected that the application specified power $\mathrm{P}$ and energy $\mathrm{E}$ are at a ratio $\mathrm{P} / \mathrm{E}$ such as: $\mathrm{P}_{2} / \mathrm{E}_{2}<\mathrm{P} / \mathrm{E}<\mathrm{P}_{1} / \mathrm{E}_{1}$. The paper includes two examples, one of a medium size and one of a large size composite supercapacitor in the format of pouch cell, designed and fabricated in this study at optimised mass to application specifications, and tested to verify the so designed performance.

\section{DESIGN OF AN APPLICATION-SPECIFIC COMPOSITE SUPERCAPACITOR}

The composite supercapacitor researched in this study consists of two capacitor elements in parallel, a high power supercapacitor cell-equivalent (C1) and a high energy supercapacitor cell-equivalent (C2). The composite supercapacitor cell or module contains a total area $\alpha$ of $(\mathrm{C} 1)$ and a total area $\beta$ of (C2). The capacitance of the composite cell, $\mathrm{C}_{\text {cell, }}$, and the resistance of the composite cell, $\mathrm{R}_{\text {cell, }}$, are determined according to equations (1) and (2), respectively:

$C_{c e l l}=\alpha c_{1}+\beta c_{2}$

where $c_{1}$ is the areal capacitance, or capacitance per unit area, of the high power supercapacitor cellequivalent $(\mathrm{C} 1)$ and $c_{2}$ is the areal capacitance of the high energy supercapacitor cell-equivalent $(\mathrm{C} 2)$. 
$\frac{1}{R_{\text {cell }}}=\frac{\alpha}{r_{1}}+\frac{\beta}{r_{2}}$

where $r_{1}$ is the areal resistance, or resistance of unit area, of the high power supercapacitor cellequivalent $(\mathrm{C} 1)$ and $\mathrm{r}_{2}$ is the areal resistance of the high energy supercapacitor cell-equivalent $(\mathrm{C} 2)$.

The application may be associated with a maximum storage energy, $\mathrm{E}_{\max }$, and a maximum power, $\mathrm{P}_{\max }$, which are given by the equations below:

$E_{\max }=\frac{1}{2} C V_{\max , o p}^{2}$

$P_{\max }=\frac{V_{\max , o p}^{2}}{4 R}$

where $\mathrm{C}$ and $\mathrm{R}$ are respectively the capacitance and resistance of the supercapacitor for the application and $\mathrm{V}_{\max , o \mathrm{p}}$ is the maximum operating voltage at a certain current after the voltage drop due to internal resistance losses at that current is deducted.

It is customary for the application specifications to include a minimum voltage, $V_{\min }$, an energy requirement at a current, $\mathrm{I}_{\mathrm{E}}$, and a power requirement at a current, $\mathrm{I}_{\mathrm{P}}$, where these requirements can be further deduced at cell level (for example if $\mathrm{N}_{\mathrm{s}}$ cells are connected in series, then $\mathrm{V}_{\text {min,cell }}=$ $\mathrm{V}_{\min } / \mathrm{N}_{\mathrm{s}}$ ). Hence, equations (3) and (4) can be translated to cell level as follows: 
$E_{c e l l}=\frac{1}{2} C_{c e l l, E}\left[\left(V_{\text {max }, \text { cell }}-I_{E} R_{\text {cell }}\right)^{2}-V_{\text {min, cell }}^{2}\right]$

$P_{\text {cell }}=\frac{V_{\text {minP,cell }}^{2}}{4 R_{\text {cell }}}$

where $E_{\text {cell }}$ is the cell energy required at current $\mathrm{I}_{\mathrm{E}}$ and $\mathrm{P}_{\text {cell }}$ is the power required at current $\mathrm{I}_{\mathrm{P}}$ (usually required to be maintained for a specified pulse duration $t_{\text {pulse, }}$ in which case the cell would reach a

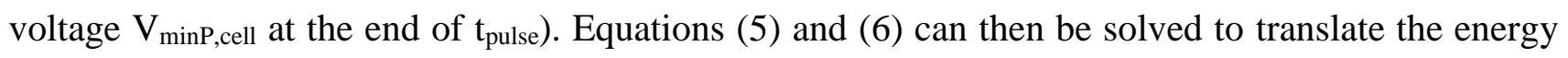
and power requirements into requirements of capacitance of the supercapacitor cell, $\mathrm{C}_{\text {cell,E }}$ at current $\mathrm{I}_{\mathrm{E}}$, and cell resistance, $\mathrm{R}_{\text {cell, }}$ (considered at $\mathrm{I}_{\mathrm{P}}$ ).

In this manner, a composite supercapacitor is designed to comply with the required cell capacitance, $\mathrm{C}_{\text {cell,E }}$ at current $\mathrm{I}_{\mathrm{E}}$, and cell resistance, $\mathrm{R}_{\text {cell, }}$, at current $\mathrm{I}_{\mathrm{P}}$ by using a total area $\alpha$ of high power cellequivalent (C1) and a total area $\beta$ of high energy cell-equivalent (C2), where $\alpha$ and $\beta$ are determined by solving equations (1) and (2).

\section{RESULTS AND DISCUSSION FOR ONE TYPE EDLC CELLS}

One type EDLC cells, high power type cells (C1) and high energy type cells (C2), were fabricated according to the configurations presented in Fig. 2 with the current collector, separator and electrolyte materials (same current collector, separator and electrolyte for (C1) and (C2) in this study) as described in section 6. The active electrodes used for each type of EDLC cell were as follows: electrode (e1) for EDLC (C1) was a coating of phenolic-derived activated carbon (AC), 5 wt\% carbon black and $3 \mathrm{wt} \%$ SBR binder; electrode (e2) for EDLC (C2) was a phenolic-derived activated carbon fabric (ACF). BET analysis yielded a specific pore surface area of $1461 \pm 34 \mathrm{~m}^{2} \mathrm{~g}^{-1}$ for the ACF electrode (e2) used in this study, $1000 \mathrm{~m}^{2} \mathrm{~g}^{-1}$ for the phenolic-derived AC powder ${ }^{[22]}$ used in 
(e1) but $866 \pm 16 \mathrm{~m}^{2} \mathrm{~g}^{-1}$ for the coating electrode (e1) used in this study, where the lower BET value for the coating compared to that of the original powder may be attributed to the SBR binder covering some of the AC powder pores also observed with $5 \mathrm{wt} \%$ PVDF binder ${ }^{[17]}$.

Fig.3 presents the pore size distribution derived using BJH analysis for each electrode, i.e. the coating electrode (e1) and the ACF electrode (e2) used in this study. It is clear that the phenolicderived AC-based coating electrode is mesoporous with the main part of the specific coating pore volume of a median pore diameter of $31 \mathrm{~nm}$ whereas the specific coating pore surface area is bimodal with a tall peak at a pore diameter of $31 \mathrm{~nm}$ and a smaller peak at a pore diameter of 1.87 nm. In contrast, the phenolic-derived ACF has a monodisperse pore size distribution with a single peak at $1.87 \mathrm{~nm}$ and a pore range starting below $7 \mathrm{~nm}$. These pore size distributions explain the high power or high energy type of the two supercapacitor electrodes (e1) and (e2), respectively: the mesoporous electrode (e1) allows for excellent mobility of the electrolyte ions though the mesopores and it allows for quick charge and discharge and leads to a high power EDLC (C1). However, the low proportion of surface area of micropores means that this electrode may not reach the high capacitance associated with micropores of similar size as the largest electrolyte ion, which is the cation $\mathrm{TEA}^{+}$in this case (limiting size of $\mathrm{TEA}^{+}$is around $0.7 \mathrm{~nm}$ in unsolvated state and $1.3 \mathrm{~nm}$ in solvated state in AN solvent) ${ }^{[9]}$, hence, (e1) may not lead to supercapacitors of the highest energy density. In contrast, (e2) has a high specific surface area consisting of micropores at a peak size close to two unsolvated cations or a solvated cation, which means that (e2) leads to supercapacitor (C2) with the potential of reaching very high energy density. However, the monodisperse nature of the pore size distribution of (e2) with a unique pore size peak at micropore size means reduced cation mobility in the limited pore width that restricts the rate of charge and discharge and the power density of supercapacitor (C2). Consequently, the comparison of the pore size distributions of 
electrodes (e1) and (e2) makes clear the power-to-energy ratio relation between the two cells, correspondingly attributing a high power to EDLC cell (C1) and a high energy to EDLC cell (C2).

Fig.4 presents the Nyquist plot from the electrochemical impedance spectroscopy (EIS) data and the galvanostatic charge-discharge (GCD) plots for a $2 \mathrm{~cm}^{2}$ EDLC cell (C1). The Nyquist plot in Fig.4(a) yields a sum of electrolyte solution and contact resistance of $0.8 \mathrm{ohm}$ translating to $1.6 \mathrm{ohm}$ for each $\mathrm{cm}^{2}(\mathrm{C} 1)$ cell. Fig.4(b) displays symmetric plots of GCD data from the discharge phase of which the Ragone plot for (C1) is derived in Fig.1(a), ranging from a maximum energy density of 24 $\mathrm{Wh} / \mathrm{kg}$ of electrodes to a maximum tested power density of $40 \mathrm{~kW} / \mathrm{kg}$ of electrodes, demonstrating the high power density of EDLC (C1). The discharge phase of the GCD data in Fig.4(b) has also been used to determine the areal resistance $r_{1}$ and areal capacitance $c_{1}$ of the high power EDLC (C1) used in this study as: $r_{1}=2.3 \mathrm{ohm}$ for each $\mathrm{cm}^{2}$ of supercapacitor cell and $\mathrm{c}_{1}=0.3072 \mathrm{~F} / \mathrm{cm}^{2}$ of cell at medium operating current density.

Fig.5 presents the Nyquist plot from the EIS data and the GCD plots for a $4 \mathrm{~cm}^{2}$ EDLC cell (C2). The Nyquist plot in Fig.5(a) yields a sum of electrolyte solution and contact resistance of $0.7 \mathrm{ohm}$, translating to $2.8 \mathrm{ohm}$ for each $\mathrm{cm}^{2}(\mathrm{C} 2)$ cell, clearly higher than that for cell (C1). Fig.5(b) displays symmetric plots of GCD data from the discharge phase of which the Ragone plot for (C2) is derived in Fig.1(b), ranging from a maximum energy density of $39 \mathrm{Wh} / \mathrm{kg}$ of electrodes to a maximum tested power density of $7 \mathrm{~kW} / \mathrm{kg}$ of electrodes, demonstrating the high energy density of EDLC (C2) in comparison to that of $(\mathrm{C} 1)$. The discharge phase of the GCD data in Fig.5(b) has also been used to determine the areal resistance $r_{2}$ and areal capacitance $c_{2}$ of the high energy EDLC (C2) used in this study as: $\mathrm{r}_{2}=8.8 \mathrm{ohm}$ for each $\mathrm{cm}^{2}$ of supercapacitor cell and $\mathrm{c}_{2}=0.71336 \mathrm{~F} / \mathrm{cm}^{2}$ of cell at medium operating current density. It is clear that $\operatorname{EDLC}(\mathrm{C} 2)$ has more than double the capacitance of EDLC (C1) but about 4 times the resistance of EDLC (C1). These values of $r_{1}, r_{2}, c_{1}, c_{2}$ for EDLC- 
equivalent (C1) and (C2) will be used in equations (1) and (2) in the design of the composite supercapacitor cells in this study.

\section{RESULTS AND DISCUSSION FOR COMPOSITE EDLCS}

Composite supercapacitor pouch cells were fabricated with integrated $\alpha \mathrm{cm}^{2}$ of high power EDLCequivalent $(\mathrm{C} 1)$ and $\beta \mathrm{cm}^{2}$ of high energy EDLC-equivalent (C2) (results of which are presented in section.3), sharing the same electrolyte, separator (S) and current collector (cc). Fig.6 presents different proposed configurations for composite EDLCs: Fig.6(a) presents an assembly of flat cells with double-sided current collectors and adjacent active electrodes (e1) or (e2) at each side and separate pieces of separator (S) sandwiched in each equivalent cell. Fig.6(b) presents a similar assembly but with a continuous separator meandering through adjacent cells in z-form. Fig.6(c) illustrates a jelly-rolled composite cell with one part of it as high power EDLC-equivalent (C1) and another part of it as high energy EDLC-equivalent (C2). Large composite EDLCs in both configurations presented in Fig.6(a) and (b) have been fabricated for this study with identical GCD results for the two configurations. We would recommend the configurations of composite EDLCs presented in Fig.6(b) and 6(c) for increased automation during manufacture.

\subsection{DESIGN AND RESULTS OF MEDIUM-SIZE COMPOSITE SUPERCAPACITOR}

An application-specific, medium-size, composite supercapacitor cell was designed according to the requirements presented in the first column of Table 1 . Given the required values of $\mathrm{R}_{\text {cell }}$ and $\mathrm{C}_{\text {cell }}$ and using the values for areal resistance and areal capacitance measured in section 3 for high power EDLC-equivalent cell (C1) and high-energy EDLC-equivalent cell (C2), the system of equations (1) and (2) was solved for $\alpha$ and $\beta$ to obtain: $\alpha=576 \mathrm{~cm}^{2}$ cell area of EDLC-equivalent (C1) and $\beta=$ $1296 \mathrm{~cm}^{2}$ cell area of EDLC-equivalent (C2). A composite supercapacitor cell was then fabricated of pouch type of rectangular flat face of $\mathrm{W}=12 \mathrm{~cm}$ width and $\mathrm{H}=12 \mathrm{~cm}$ height. This involved four cells 
of type $(\mathrm{C} 1)$ of $12 \times 12=576 \mathrm{~cm}^{2}$ cell area and nine cells of type $(\mathrm{C} 2)$ of cell area of $1296 \mathrm{~cm}^{2}$. Table 1 presents the mass of each individual component in the pouch composite supercapacitor cell with the total mass being $186.5 \mathrm{~g}$.

If only active electrode (e1) were used for designing an EDLC of type (C1), an area of $920 \mathrm{~cm}^{2}$ of (C1) supercapacitor cell is needed $\left(\alpha=r_{1} / R_{\text {cell }}=920 \mathrm{~cm}^{2}\right)$ to cover the application-specific resistance requirement. In order to cover the application-specific capacitance requirement an area of $3581 \mathrm{~cm}^{2}$ of $(\mathrm{C} 1)$ supercapacitor cell is needed $\left(\alpha=\mathrm{C}_{\text {cell }} / \mathrm{c}_{1}=3581 \mathrm{~cm}^{2}\right)$. It is clear in this case for the high power EDLC (C1), its energy (cell capacitance) is the limiting factor in satisfying the requirements of the application, hence, $3581 \mathrm{~cm}^{2}$ of EDLC (C1) is needed to satisfy all requirements of the application. After summing the mass of all individual components as presented in Table 1, the medium-size EDLC of high power type cell (C1) had a total mass of $297.7 \mathrm{~g}$. This means that the composite EDLC satisfying the requirements of Table 1 has achieved $40 \%$ reduction in mass and weight compared to the equivalent EDLC of type (C1) only.

If only active electrode (e2) were used for designing an EDLC of type (C2) only, an area of 3520 $\mathrm{cm}^{2}$ of $(\mathrm{C} 2)$ supercapacitor cell is needed $\left(\beta=\mathrm{r}_{2} / \mathrm{R}_{\text {cell }}=3520 \mathrm{~cm}^{2}\right)$ to cover the application-specific resistance requirement. In order to cover the application-specific capacitance requirement an area of $1542 \mathrm{~cm}^{2}$ of (C2) supercapacitor cell is needed $\left(\beta=\mathrm{C}_{\text {cell }} / \mathrm{c}_{2}=1542 \mathrm{~cm}^{2}\right)$. It is clear in this case for the high energy EDLC (C2), its power (cell resistance) is the limiting factor in satisfying the requirements of the application, hence, $3520 \mathrm{~cm}^{2}$ of EDLC (C2) is needed to satisfy all requirements of the application. After summing the mass of all individual components as presented in Table 1, the medium-size EDLC of high energy type cell (C2) had a total mass of $360.2 \mathrm{~g}$. This means that the composite EDLC satisfying the requirements of Table 1 has achieved $50 \%$ reduction in mass and weight compared to the equivalent EDLC of type (C2) only. 
Fig.7 presents the GCD test data at $\pm 10 \mathrm{~A}$ and $\pm 50 \mathrm{~A}$, respectively, for the medium-size composite supercapacitor cell connected with cables of $2 \mathrm{~m} \Omega$ resistance. The tests were conducted using a $\mathrm{H} \& \mathrm{H}$ test analyser with 2 cables of $2 \mathrm{~m}$ each, where the cables had a $2 \mathrm{~m} \Omega$ resistance that is included in the tested supercapacitor system and has affected the voltage measurements of the graphs in Fig.7. From this data it has been calculated (after the cable resistance has been deducted) that the resistance of the composite cell is $R_{\text {cell }}=2.66 \mathrm{~m} \Omega$ and $\mathrm{C}_{\text {cell, } 10 \mathrm{~A}}=1093 \mathrm{~F}$ (against the required $\mathrm{C}_{\text {cell, }, 12.8 \mathrm{~A}}=1100$ F). Hence, taking also into account an existing $\pm 10 \%$ variation in the material properties of the fabricated supercapacitor cell, it has been proven that the composite supercapacitor cell has $\mathrm{R}_{\text {cell }}$ and $\mathrm{C}_{\text {cell,E }}$ close to the values determined by equations (1) and (2) for the design and calculations of the quantities of each type of cell and materials of the composite supercapacitor cell to satisfy the power and energy requirements of the application of interest.

\subsection{DESIGN AND RESULTS OF LARGE-SIZE COMPOSITE SUPERCAPACITOR}

An application-specific composite supercapacitor cell was fabricated for a $12 \mathrm{~V}$ transient start stop application (TSS) for micro-hybrid vehicles. The specifications were from the FreedomCAR program ${ }^{[8]}$ and included the following key targets for the supercapacitor system: voltage range: 17 Vdc to $9 \mathrm{Vdc}$; power: $4.2 \mathrm{~kW}$ for pulse duration of $2 \mathrm{~s}$; available energy at $1 \mathrm{~kW}: 15 \mathrm{Wh}$.

Given that the electrolyte to be used is $1.5 \mathrm{M} \mathrm{TEABF}_{4}$ in acetonitrile, a safe maximum operating voltage for EDLC cells with this electrolyte is $2.7 \mathrm{~V}$. So seven such supercapacitor cells/modules in series are needed to achieve the maximum voltage limit of the application. This means that the application requires for each cell/module in series a maximum voltage of $17 \mathrm{~V} / 7=2.43 \mathrm{~V}$. The minimum operating voltage for each cell/module in series is $9 \mathrm{~V} / 7=1.286 \mathrm{~V}$. Each of these seven supercapacitor cells is required to operate in the voltage range of $2.43 \mathrm{~V}$ to $1.286 \mathrm{~V}$, providing 
$4200 \mathrm{~W} / 7=600 \mathrm{~W}$ high power for at least 2 seconds, and $15 \mathrm{Wh} / 7=2.1 \mathrm{Wh}$ energy at $143 \mathrm{~W}$ power $(=1000 \mathrm{~W} / 7)$. A mean high current considered to be required for each module in its high power phase is calculated as: $600 \mathrm{~W} /((2.43 \mathrm{~V}+1.286 \mathrm{~V}) / 2)=323 \mathrm{~A}$.

Considering equations (5) and (6) the following requirements have been derived: a required cell resistance $\mathrm{R}_{\text {cell }}=0.59 \mathrm{~m} \Omega$ or lower, a required cell capacitance $\mathrm{C}_{\text {cell, } \mathrm{P}}=3380 \mathrm{~F}$ at the high current $\mathrm{IP}_{\mathrm{P}}$ $=323 \mathrm{~A}$, and a required cell capacitance $\mathrm{C}_{\text {cell, } \mathrm{E}}=3660 \mathrm{~F}$ at medium current $\mathrm{I}_{\mathrm{E}}=77 \mathrm{~A}$.

An application-specific, large-size, composite supercapacitor cell was designed according to the requirements presented in the first column of Table 2 . Given the required values of $R_{\text {cell }}$ and $C_{\text {cell,E }}$ and using the values for areal resistance and areal capacitance measured in section 3 for high power EDLC-equivalent cell (C1) and high-energy EDLC-equivalent cell (C2), the system of equations (1) and (2) was solved for $\alpha$ and $\beta$ to obtain: $\alpha=2880 \mathrm{~cm}^{2}$ cell area of EDLC-equivalent $(\mathrm{C} 1)$ and $\beta=$ $3888 \mathrm{~cm}^{2}$ cell area of EDLC-equivalent (C2). A large composite supercapacitor cell was then fabricated of pouch type of rectangular flat face of $\mathrm{W}=12 \mathrm{~cm}$ width and $\mathrm{H}=12 \mathrm{~cm}$ height. This involved 20 cells of type (C1) and 27 cells of type (C2). Table 2 presents the mass of each individual component in the large pouch composite supercapacitor cell with the total mass being $555.5 \mathrm{~g}$.

If only active electrode (e1) were used for designing a large EDLC cell of type (C1), an area of 3898 $\mathrm{cm}^{2}$ of (C1) supercapacitor cell is needed $\left(\alpha=\mathrm{r}_{1} / \mathrm{R}_{\text {cell }}=3898 \mathrm{~cm}^{2}\right)$ to cover the application-specific resistance requirement (governing the high power achieved according to the power requirement). In order to cover the application-specific capacitance requirement at $\mathrm{I}_{\mathrm{E}}$ (affecting the stored energy which should comply with the energy requirement of $2.1 \mathrm{Wh})$ an area of $11914 \mathrm{~cm}^{2}$ of (C1) supercapacitor cell is needed $\left(\alpha=\mathrm{C}_{\text {cell }} / \mathrm{c}_{1}=11914 \mathrm{~cm}^{2}\right)$. It is clear in this case for the high power EDLC (C1), its energy (cell capacitance) is the limiting factor in satisfying the requirements of the 
application, hence $11914 \mathrm{~cm}^{2}$ of EDLC (C1) is needed to satisfy all requirements of the application. After summing the mass of all individual components as presented in Table 2, the large-size EDLC of high power type cell (C1) had a total mass of $932.2 \mathrm{~g}$. This means that the large composite EDLC cell satisfying the requirements of Table 2 has achieved $40 \%$ reduction in mass and weight compared to the equivalent EDLC of type (C1) only.

If only active electrode (e2) were used for designing a large EDLC of type (C2) only, an area of $14915 \mathrm{~cm}^{2}$ of $(\mathrm{C} 2)$ supercapacitor cell is needed $\left(\beta=\mathrm{r}_{2} / \mathrm{R}_{\text {cell }}=14915 \mathrm{~cm}^{2}\right)$ to cover the applicationspecific resistance requirement. In order to cover the application-specific capacitance requirement at $\mathrm{I}_{\mathrm{E}}$ an area of $5701 \mathrm{~cm}^{2}$ of (C2) supercapacitor cell is needed $\left(\beta=\mathrm{C}_{\text {cell }} / \mathrm{c}_{2}=5701 \mathrm{~cm}^{2}\right)$. It is clear in this case for the high energy EDLC (C2), its power (cell resistance) is the limiting factor in satisfying the requirements of the application, hence $14915 \mathrm{~cm}^{2}$ of EDLC (C2) is needed to satisfy all requirements of the application. After summing the mass of all individual components as presented in Table 2, the large-size EDLC of high emergy type cell (C2) had a total mass of $1338.4 \mathrm{~g}$. This means that the large composite EDLC cell satisfying the requirements of Table 2 has achieved 58\% reduction in mass and weight compared to the equivalent EDLC of type (C2) only.

Fig.8 presents the GCD test data at \pm 75 A and \pm 300 A, respectively, for the large composite supercapacitor cell connected with cables of $1 \mathrm{~m} \Omega$ resistance. The tests were conducted using a $\mathrm{H} \& \mathrm{H}$ test analyser with 2 cables of $1 \mathrm{~m}$ each, where the cables had a $1 \mathrm{~m} \Omega$ resistance that is included in the tested supercapacitor system and has affected the voltage measurements of the graphs in Fig.8. From this data and the standard error from the statistical analysis of the same type of test data of eight large composite supercapacitor cells fabricated and tested as in the example of section 4.2, it has been calculated that the resistance of the composite cell is $R_{\text {cell }}=0.5 \pm 0.1 \mathrm{~m} \Omega$ (after the cable resistance has been deducted), $\mathrm{C}_{\text {cell, } 300 \mathrm{~A}}=3480 \pm 100 \mathrm{~F}$ (against the required $\mathrm{C}_{\text {cell, } 323 \mathrm{~A}}=3380 \mathrm{~F}$ ), and 
$\mathrm{C}_{\text {cell, } 75 \mathrm{~A}}=3700 \pm 100 \mathrm{~F}$ (against the required $\mathrm{C}_{\text {cell,77A }}=3660 \mathrm{~F}$ ). Hence, it has been proven that the large composite supercapacitor cell has $\mathrm{R}_{\text {cell }}$ and $\mathrm{C}_{\text {cell,E }}$ close to the values determined by equations (1) and (2) for the design and calculations of the quantities of each type of cell and materials of the composite supercapacitor cell to satisfy the power and energy requirements of the application of interest.

\section{CONCLUSION}

This study has proposed a novel composite supercapacitor comprising an integrated cell consisting of high power-related electrode material and high energy-related electrode material so that the composite supercapacitor can satisfy a given power-to-energy ratio. A precise methodology has been proposed for the design of the composite supercapacitor and the prediction of the required quantity of each type of electrode and each type of cell-equivalent, high power and high energy respectively connected in parallel, according to the rule of mixtures for the composite capacitance and the inverse rule of mixtures for the composite resistance, on the basis of the known areal capacitance and areal resistance of each type of cells. This methodology has been applied in this study for designing application-specific composite supercapacitors of medium and large size. These composite supercapacitors have been fabricated in the form of pouch cell and tested in galvanostatic chargedischarge tests. The test data have proven that their performance matches the designed performance according to the specifications of the application of interest and, hence, the design methodology for the composite supercapacitor, proposed in this paper, has been proven correct.

The novel composite supercapacitor proposed in this study offers huge advantages in weight reduction and substantial increase of the energy and power density of an application-specific supercapacitor. Both medium size and large size composite supercapacitors designed, fabricated and tested for the application examples in this study offered 40-60\% weight reduction compared with a 
supercapacitor made from the high power only electrode material (AC coating-based supercapacitor) or the high energy only electrode (AC fabric-based supercapacitor) with the same specifications for the same application, with the same organic electrolyte, separator and other pouch cell materials.

\section{MATERIALS AND EXPERIMENTAL TECHNIQUES}

Symmetric EDLC cells (either of the same active electrode material or of two different active electrode materials for composite cells) were fabricated consisting of the following components and materials. The current collector was Toyal-Carbo ${ }^{\circledR}$ foil (Toyal Toyo Aluminium K.K.), which is an aluminium foil with embedded $\mathrm{Al}_{4} \mathrm{C}_{3}$ whiskers protruding over the foil surface and anchoring carbon black nanoparticles $(20-30 \mathrm{~nm})$, with this modification lowering the contact resistance between the current collector and the active electrodes ${ }^{[23]}$. The active electrode material for the high power cells and high power-equivalent cell (C1) was a coating of phenolic-derived activated carbon (AC) TE320 with about 30\% activation (from MAST Carbon International, Ltd) ${ }^{[22]}$, 5 wt $\%$ acetylene carbon black (from Alfa Aesar with specifications of average particle size of $42 \mathrm{~nm}$, specific surface area of $75 \mathrm{~m}^{2} \mathrm{~g}^{-1}$ and bulk density in the range of $170-230 \mathrm{~kg} \mathrm{~cm}^{-3}$ ) and $3 \mathrm{wt} \% \mathrm{SBR}$ binder (modified styrene-butadiene copolymer hydrophilic binder PSBR100 from Targray in 15\% SBR aqueous emulsion). A slurry of these materials in water was coated onto the current collector foil via the doctor blade technique and the coating was dried at $80{ }^{\circ} \mathrm{C}$. The active electrode material for the high energy cells and high energy-equivalent cell (C2) was phenolic-derived activated carbon fabric ACC-507-15 (bulk batch of $70 \mathrm{~m}^{2}$ ACF purchased from Kynol Europe Gmbh) of a nominal thickness of $0.5 \mathrm{~mm}$, a measured average areal density of $12.05 \mathrm{mg} \mathrm{cm}^{-2}$ and a measured BET area of $1461 \mathrm{~m}^{2} \mathrm{~g}^{-1}$. The ACF was placed adjacent to the current collector without using any binder or any further treatment. The separator in the middle of each cell was a cellulose-based paper separator, NKK TF4060 (NKK - Nippon Kodoshi Corp) of $60 \mu \mathrm{m}$ thickness. An organic electrolyte was used: 
1.5 $\mathrm{M} \mathrm{TEABF}_{4}$ (tetraethyl ammonium tetrafluoroborate) in AN (acetonitrile) (> 99\% purity from Sigma Aldrich; anhydrous with > 99.8\% purity from Alfa Aesar Ltd, respectively).

Pouch cells were constructed utilising aluminium-polypropylene film laminated foil (from MTI with a thickness of $115 \mu \mathrm{m}$ ) for medium size and large pouch cells. Terminal tabs for intermediate size and large size pouch cells were made from $100 \mu \mathrm{m}$ sheet aluminium and were ultrasonically welded to the aluminium foil of the Toyal-Carbo ${ }^{\circledR}$ current collectors. The electrode stack was dried under vacuum at $80{ }^{\circ} \mathrm{C}$ for 24 hours. Once dried the electrode stack was wrapped with aluminiumpolypropylene film laminated foil and sealed on three edges. The electrolyte was inserted in the fourth side and rapidly sealed under vacuum utilising an Audionvac VMS 153V.

BET and BJH analysis of electrodes was conducted with a Micrometrics Gemini V 2380. Small cells were tested in electrochemical impedance spectroscopy (EIS) (1 MHz to $10 \mathrm{mHz}$ frequencies) and all cells were tested in galvanostatic charge-discharge (GCD) at different currents. Small cells were tested with a VERSASTAT MC (Princeton Inc). For testing medium and large-size cells a Hoecherl \& Hackl NL1V8C320 source-sink device was used with a maximum voltage of $8 \mathrm{~V}$ and a maximum current output of \pm 320 A. Ragone plots (energy density versus power density of a cell) were constructed from the discharge phase GCD data at different current densities.

\section{ACKNOWLEDGEMENTS}

This study has been partially funded by the European FP7 project AUTOSUPERCAP, GA No 266097. 


\section{REFERENCES}

[1] F. Marloulidis, C. Lei, C. Lekakou, submitted, J. Power Sources, 2015.

[2] A. Santucci, A. Sorniotti, C. Lekakou, J. Power Sources, 2014, 258, 395-407.

[3] A. Lahyani, P. Venet, A. Guermazi, A. Troudi, Power Electronics, IEEE Transactions on. 2013, 28, 1509-1522.

[4] "The role of energy storage for mini-grid stabilization": B. Espinar, D. Mayer in IEA-PVPS, 2011, http://iea-pvps.org/index.php?id=227\&eID=dam_frontend_push\&docID=744, accessed 29 July 2015.

[5] J. Marcos, I. de la Parra, M. García, L. Marroyo, Energies, 2014, 7, 6593-6619.

[6] Z. Hengbing, A. Burke, Fuel Cell Powered Vehicles Using Supercapacitors: Device Characteristics, Control Strategies, and Simulation Results. Institute of Transportation Studies, University of California, Research Report UCD-ITS-RR-10-01, 2010.

[7] A.R.T. Bambang, A.S. Rohman, C.J. Dronkers. R. Ortega, A. Sasongko, Industrial Informatics, IEEE Transactions on. 2014, 10, 1992-2002.

[8] National Renewable Energy Laboratory, Ultracapacitors and Batteries in Hybrid Vehicles, 2005, http://www.nrel.gov/transportation/energystorage/pdfs/38484.pdf, accessed 8 March 2015.

[9] J. Huang, B. G. Sumpter, V. Meunier, Chem. - Eur. J. 2008, 14, 6614-6626.

[10] L. Pilon, H. Wang, A. d'Entremont, J. Electrochem. Soc. 2015, 162 A5158-A5178.

[11] P. Bajaj, A. Dhawan, Indian J. Fibre Text. Res. 1997, 22, 222-235.

[12] A. Pandolfo, A. Hollenkamp, J. Power Sources, 2006, 57, 11-27.

[13] A. Pandolfo, G. Wilson, T. Huynh, A. Hollenkamp, Fuel Cells, 2010, 5, 856-864.

[14] R. Chandrasekaran, Y. Soneda, J. Yamashita, M. Kodam, H. Hatori, J. Solid State Electrochem. 2008, 12, 1349-1355. 
[15] P. Kossyrev, J. Power Sources, 2012, 201, 347-352.

[16] C. Lei, C. Lekakou, Surface and Coatings Technology, 2013, 232, 326-330.

[17] F. Markoulidis, C. Lei, C. Lekakou, D. Duff, S. Khalil, B. Martorana, I. Cannavaro, Carbon, 2014, $68,58-66$.

[18] E. Vermisoglou, E. Devlin, T. Giannakopoulou, G. Romanos, N. Boukos, V. Psycharis, C. Lei, C. Lekakou, D. Petridis, C. Trapalis, J. Alloys Compd. 2014, 590, 102-109.

[19] D. Cericola, R. Kötz, Electrochimica Acta, 2012, 72, 1-17.

[20] Y.Yin, C.Liu, S.Fan, RSC Adv. 2014, 4, 26378-26382.

[21] R.F. Gibson, Composites Engineering Handbook (Eds.: P.K. Mallick), Marcel Dekker Inc., New York, 1997, pp. 167-202.

[22] C. Lei, N. Amini, F. Markoulidis, P. Wilson, S. Tennison, C. Lekakou, J. Mater. Chem. A. 2013, $1,6037-6042$.

[23] C. Lei, F. Markoulidis, C. Lekakou, Z. Ashitaka, Electrochimica Acta, 2013, 92, 183-187. 
TABLES

Table 1. Specifications and results for medium-size composite supercapacitor and equivalent single-type supercapacitors

\begin{tabular}{|c|c|c|c|c|}
\hline & Requirements & $\begin{array}{l}\text { Composite } \\
\text { EDLC }\end{array}$ & EDLC (C1) only & EDLC (C2) only \\
\hline $\mathrm{V}_{\text {max,cell }}[\mathrm{V}]$ & 2.43 & 2.43 & 2.43 & 2.43 \\
\hline $\mathrm{V}_{\text {min,cell }}[\mathrm{V}]$ & 1.286 & 1.286 & 1.286 & 1.286 \\
\hline $\mathrm{IP}[\mathrm{A}]$ & 54 & 54 & 54 & 54 \\
\hline $\mathrm{I}_{\mathrm{E}}[\mathrm{A}]$ & 12.8 & 12.8 & 12.8 & 12.8 \\
\hline $\mathrm{R}_{\text {cell }}[\mathrm{m} \Omega]$ & 2.5 & 2.66 (measured) & 0.64 & 2.5 \\
\hline $\mathrm{C}_{\text {cell }}[\mathrm{F}]$ & 1100 & 1093 (measured) & 1100 & 2511 \\
\hline$\alpha\left[\mathrm{cm}^{2}\right]$ & & 576 & 3581 & \\
\hline$\beta\left[\mathrm{cm}^{2}\right]$ & & 1296 & & 3520 \\
\hline (e1) $[\mathrm{g}]$ & & 9.2 & 57.3 & \\
\hline (e2 ) $[\mathrm{g}]$ & & 31.2 & & 84.8 \\
\hline Separator $[\mathrm{g}]$ & & 6.4 & 11.5 & 10 \\
\hline Electrolyte [g] & & 86.2 & 161.9 & 198.5 \\
\hline (cc) $[\mathrm{g}]$ & & 14.1 & 35.5 & 31.9 \\
\hline Tags $[\mathrm{g}]$ & & 22.8 & 19 & 19 \\
\hline Pouch bag [g] & & 16.6 & 12.5 & 16 \\
\hline TOTAL MASS [g] & & 186.5 & 297.7 & 360.2 \\
\hline
\end{tabular}


Table 2. Specifications and results for large-size composite supercapacitor and equivalent single-type supercapacitors

\begin{tabular}{|c|c|c|c|c|}
\hline & Requirements & $\begin{array}{l}\text { Composite } \\
\text { EDLC }\end{array}$ & EDLC (C1) only & EDLC (C2) only \\
\hline $\mathrm{V}_{\text {max,cell }}[\mathrm{V}]$ & 2.43 & 2.43 & 2.43 & 2.43 \\
\hline $\mathrm{V}_{\text {min,cell }}[\mathrm{V}]$ & 1.286 & 1.286 & 1.286 & 1.286 \\
\hline $\mathrm{IP}[\mathrm{A}]$ & 323 & 323 & 323 & 323 \\
\hline $\mathrm{I}_{\mathrm{E}}[\mathrm{A}]$ & 77 & 77 & 77 & 77 \\
\hline $\mathrm{R}_{\text {cell }}[\mathrm{m} \Omega]$ & 0.59 & 0.5 (measured) & 0.19 & 0.59 \\
\hline $\mathrm{C}_{\text {cell, } \mathrm{E}}[\mathrm{F}]$ & 3660 & 3700 (measured) & 3660 & 10640 \\
\hline$\alpha\left[\mathrm{cm}^{2}\right]$ & & 2880 & 11914 & \\
\hline$\beta\left[\mathrm{cm}^{2}\right]$ & & 3888 & & 14915 \\
\hline (e1) $[\mathrm{g}]$ & & 46.1 & 191 & \\
\hline$(\mathrm{e} 2)[\mathrm{g}]$ & & 93.3 & & 360.9 \\
\hline Separator $[\mathrm{g}]$ & & 22.6 & 39 & 48.8 \\
\hline Electrolyte $[\mathrm{g}]$ & & 290.2 & 540 & 845 \\
\hline (cc) $[\mathrm{g}]$ & & 45.2 & 79 & 99.5 \\
\hline Tags $[\mathrm{g}]$ & & 34.2 & 34.2 & 34.2 \\
\hline Pouch bag [g] & & 23.9 & 40 & 40 \\
\hline TOTAL MASS [g] & & 555.5 & 923.2 & 1338.4 \\
\hline
\end{tabular}




\section{FIGURE CAPTIONS}

Fig.1 Ragone plots of EDLC cells of (a) high power density, based on AC coatings and (b) high energy density, based on phenolic-derived AC fabrics.

Fig.2 Diagrams of high power density-type EDLC cell (C1) and high energy density-type EDLC cell (C2), where: (cc) is a current collector, (e1) is an active electrode for high power-type cell, (e2) is an active electrode for high energy-type cell, (S1), (S2) or (S) are separators for cell (C1), (C2) or common separator, respectively.

Fig.3 Pore size distributions from BJH analysis of electrode coating (e1) (phenolic-derived AC + $5 \% \mathrm{CB}+3 \% \mathrm{SBR})$ and $\mathrm{ACF}$ electrode (e2) (507-15 Kynol bulk) used in high power-type cell (C1) and high energy-type cell (C2), respectively, in this study.

Fig.4 Test data of single, small EDLC cells $\left(2 \mathrm{~cm}^{2}\right)$ of high power-type (C1) used in this study: (a) Nyquist plot from EIS data in the frequency range of $1 \mathrm{MHz}$ to $10 \mathrm{mHz}$; (b) GCD test data at different current densities.

Fig.5 Test data of single, small EDLC cells $\left(4 \mathrm{~cm}^{2}\right)$ of high energy-type (C2) used in this study: (a) Nyquist plot from EIS data in the frequency range of $1 \mathrm{MHz}$ to $10 \mathrm{mHz}$; (b) GCD test data at different current densities.

Fig.6 Diagrams of proposed forms of composite EDLC supercapacitors consisting of basic cell types (C1) and (C2), depending on the type of active electrode (e1) or (e2), respectively, and shared current collectors (cc): (a) Separate separator membranes for each cell (common separator S or two 
separators (S1) and (S2) for cell-types (C1) and (C2), respectively). (b) Meander-shaped separator (S). (c) Jelly-rolled type of composite cell.

Fig.7 GCD data for the medium-size composite supercapacitor cell at $10 \mathrm{~A}$ and $50 \mathrm{~A}$.

Fig.8 GCD data for the large-size composite supercapacitor cell at $75 \mathrm{~A}$ and $300 \mathrm{~A}$. 


\section{FIGURES}

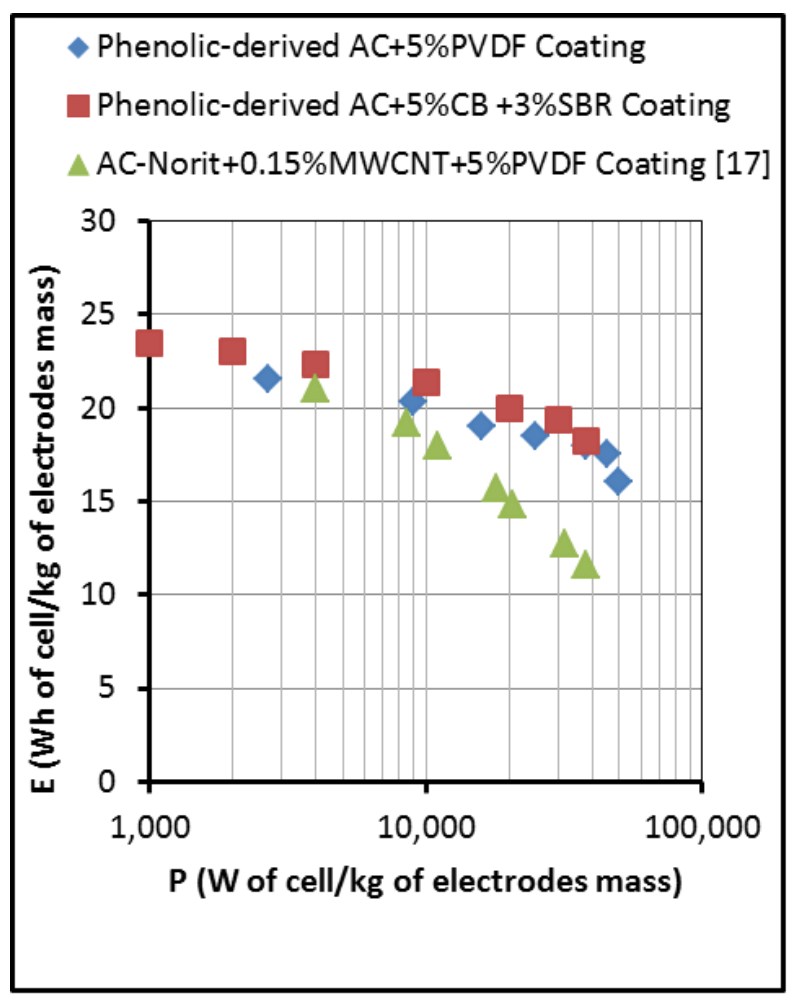

(a)

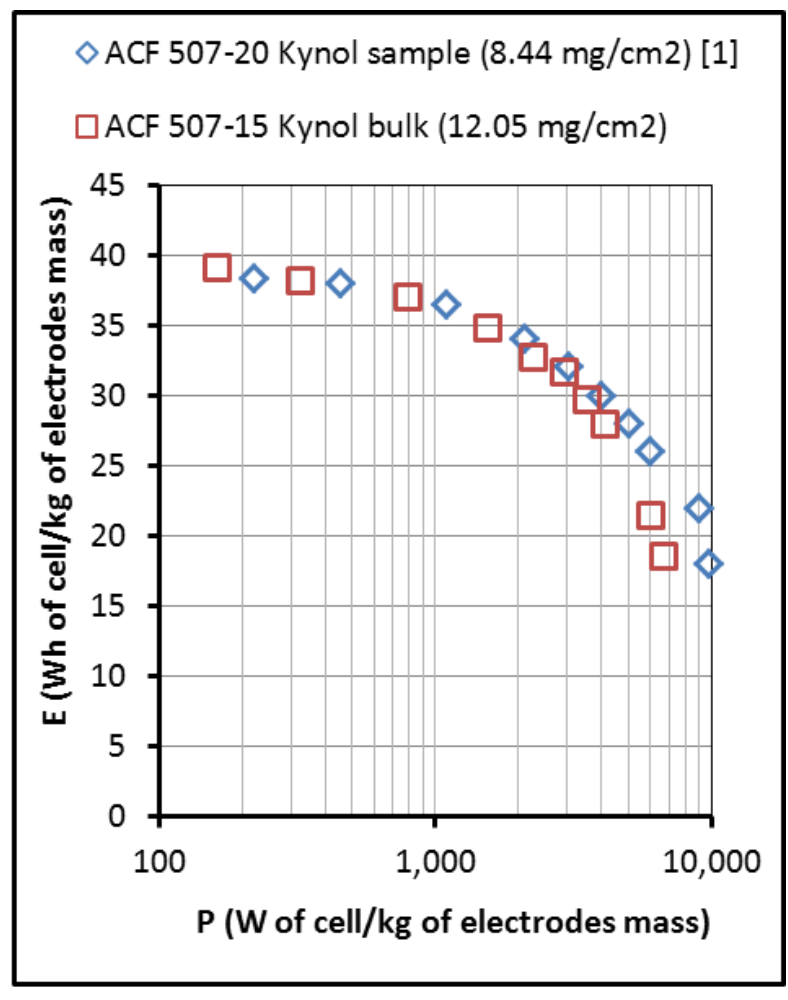

(b)

Fig.1 Ragone plots of EDLC cells of (a) high power density, based on AC coatings and (b) high energy density, based on phenolic-derived AC fabrics. 
(C1)

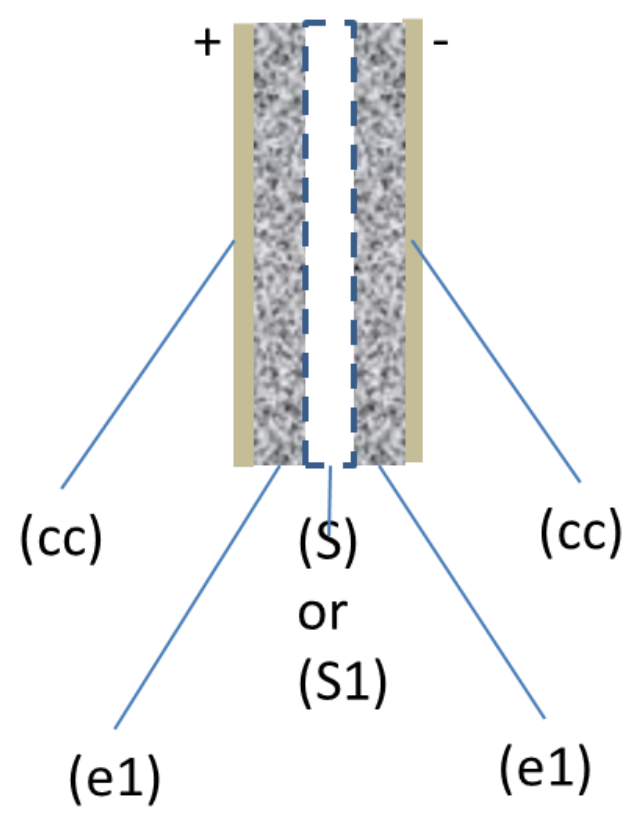

(C2)

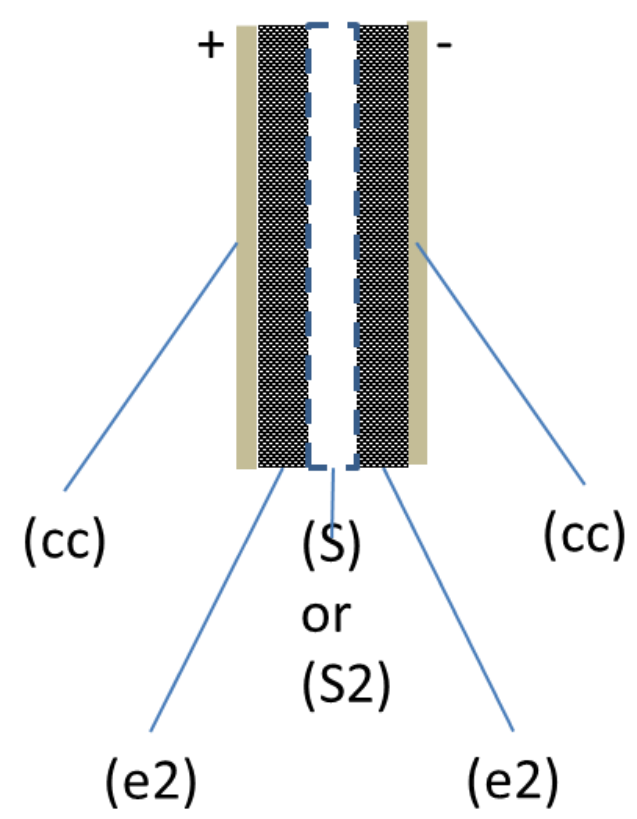

Fig.2 Diagrams of high power density-type EDLC cell (C1) and high energy density-type EDLC cell (C2), where: (cc) is a current collector, (e1) is an active electrode for high power-type cell, (e2) is an active electrode for high energy-type cell, $(\mathrm{S} 1),(\mathrm{S} 2)$ or $(\mathrm{S})$ are separators for cell $(\mathrm{C} 1),(\mathrm{C} 2)$ or common separator, respectively. 

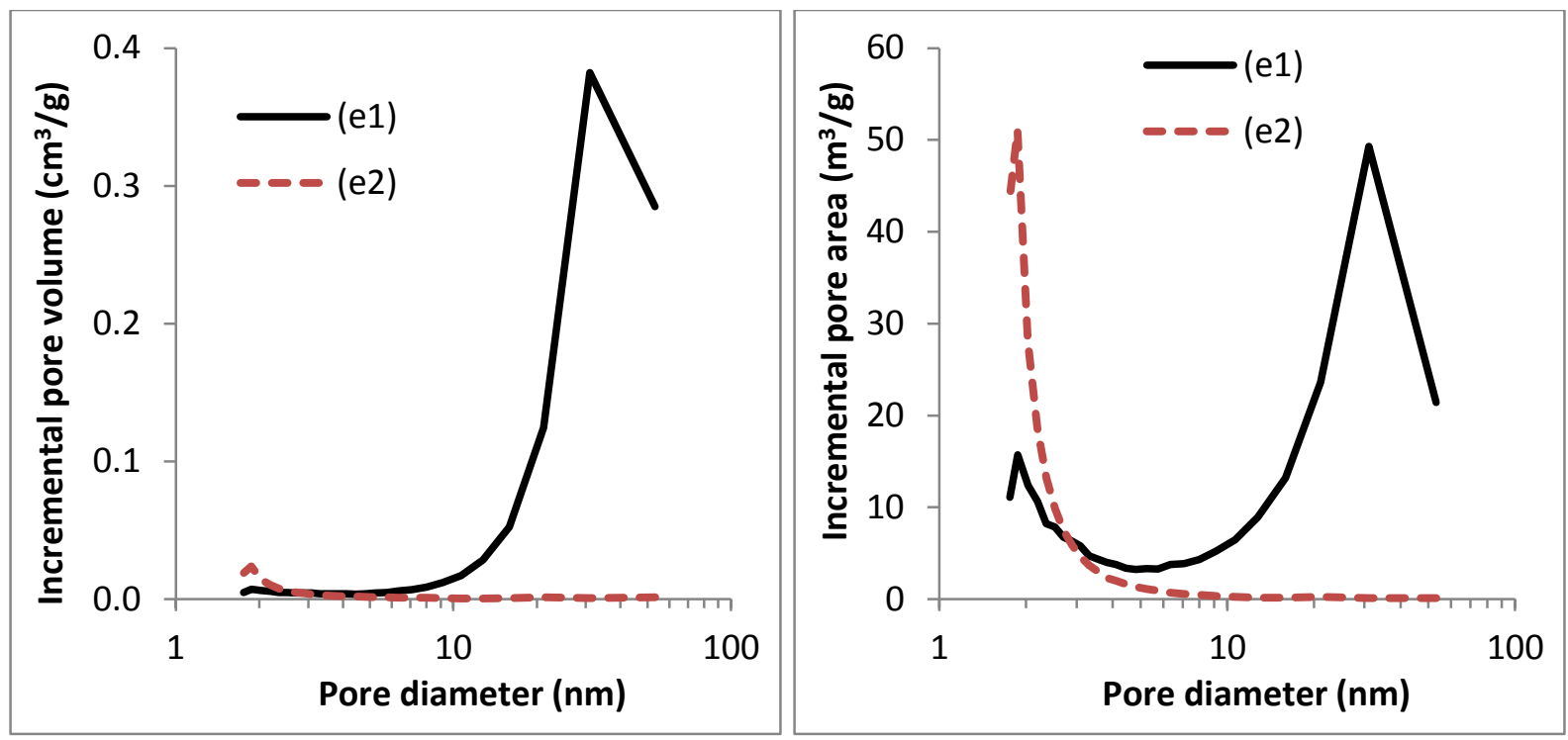

Fig.3 Pore size distributions from BJH analysis of electrode coating (e1) (phenolic-derived AC + $5 \% \mathrm{CB}+3 \% \mathrm{SBR})$ and $\mathrm{ACF}$ electrode (e2) (507-15 Kynol bulk) used in high power-type cell (C1) and high energy-type cell (C2), respectively, in this study. 


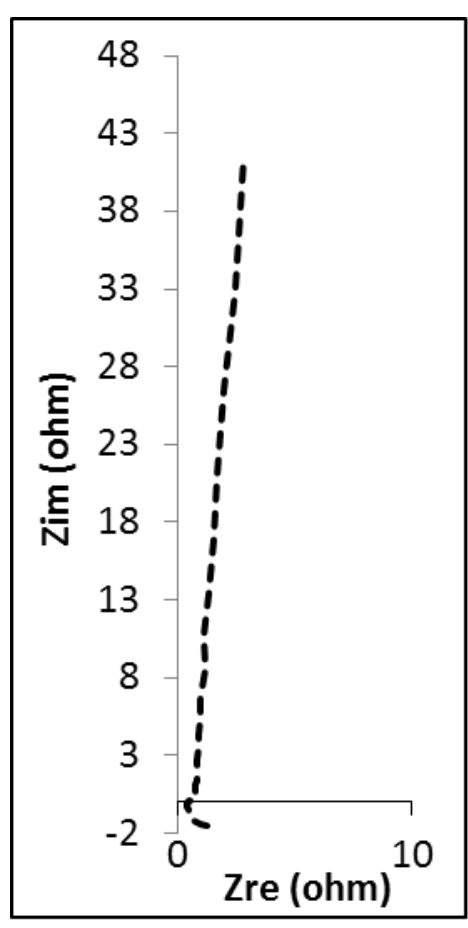

(a)

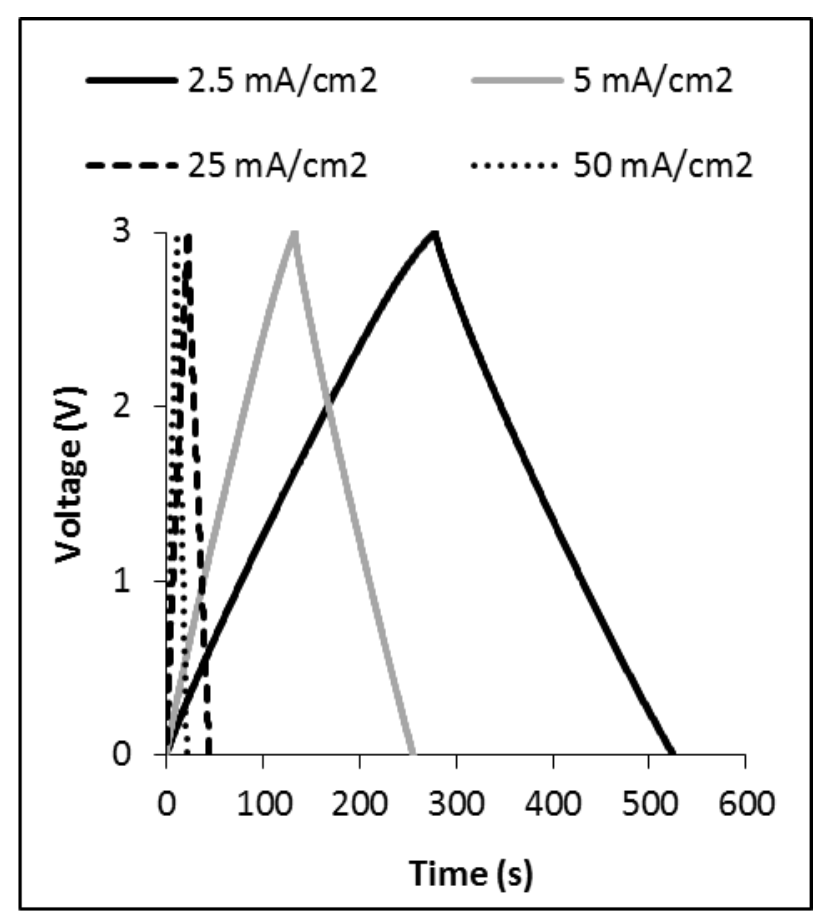

(b)

Fig.4 Test data of single, small EDLC cells $\left(2 \mathrm{~cm}^{2}\right)$ of high power-type (C1) used in this study: (a) Nyquist plot from EIS data in the frequency range of $1 \mathrm{MHz}$ to $10 \mathrm{mHz}$; (b) GCD test data at different current densities. 


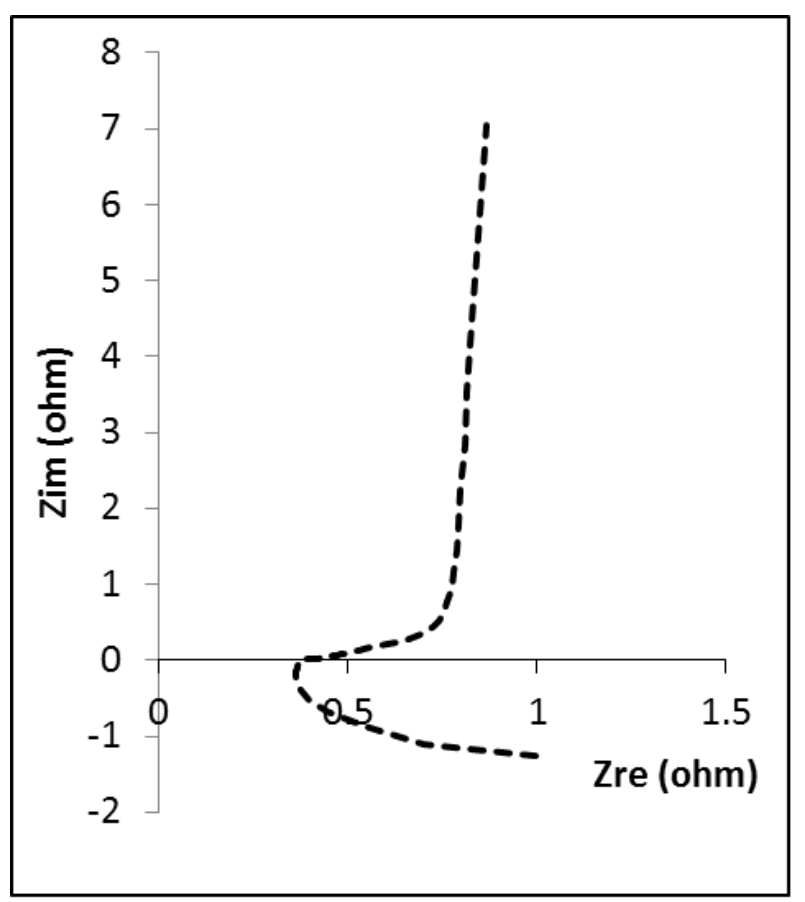

(a)

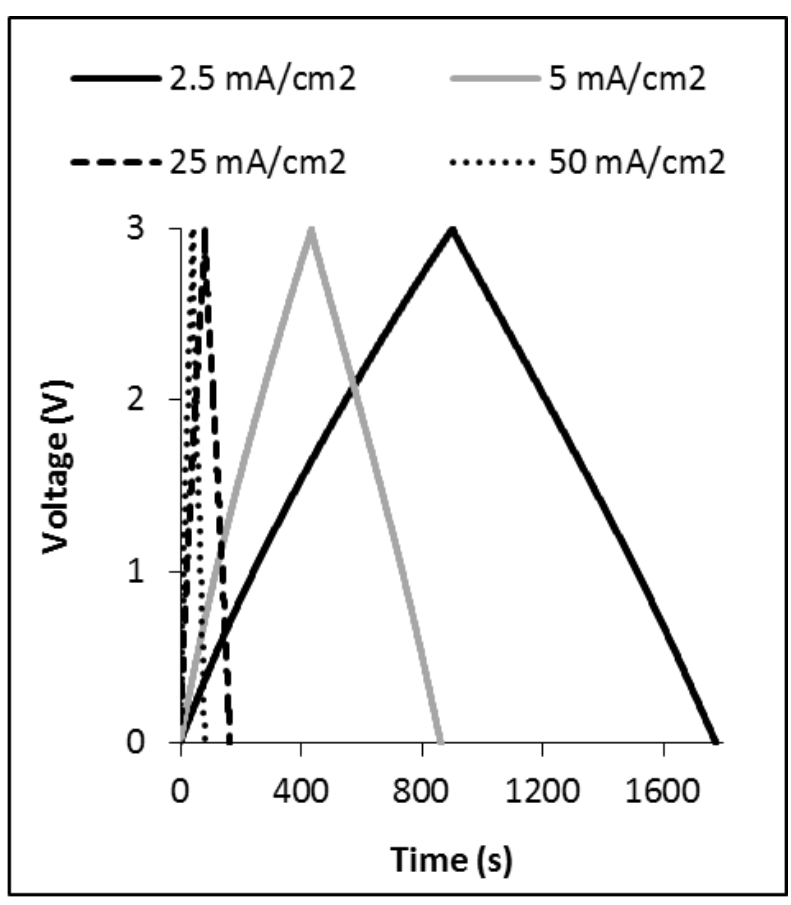

(b)

Fig.5 Test data of single, small EDLC cells $\left(4 \mathrm{~cm}^{2}\right)$ of high energy-type (C2) used in this study: (a) Nyquist plot from EIS data in the frequency range of $1 \mathrm{MHz}$ to $10 \mathrm{mHz}$; (b) GCD test data at different current densities. 


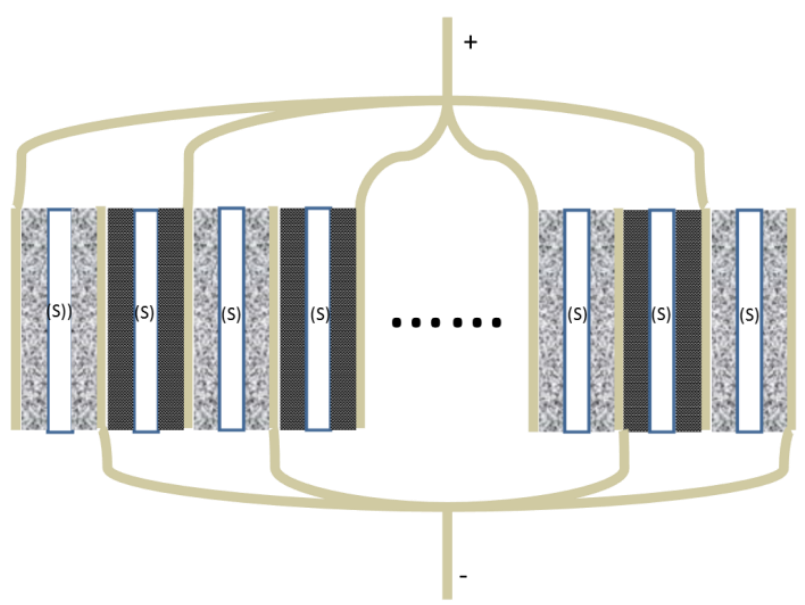

(a)

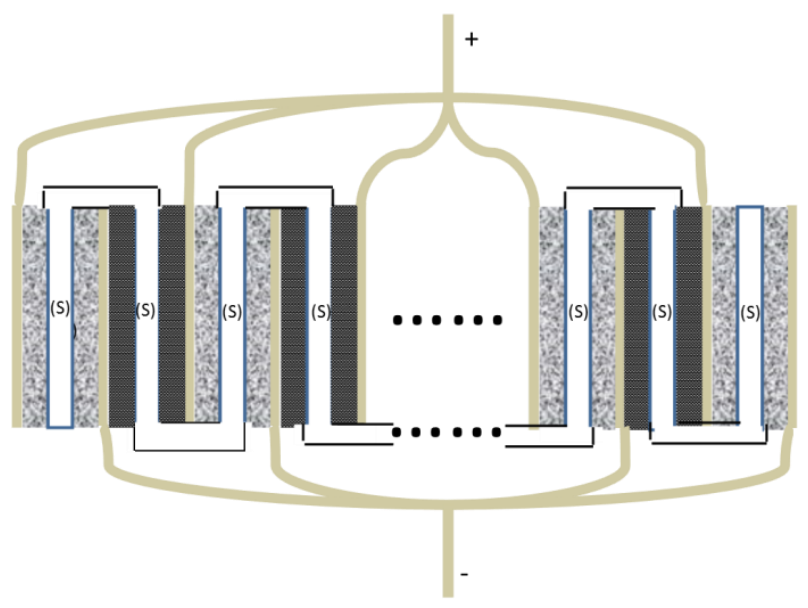

(b) 


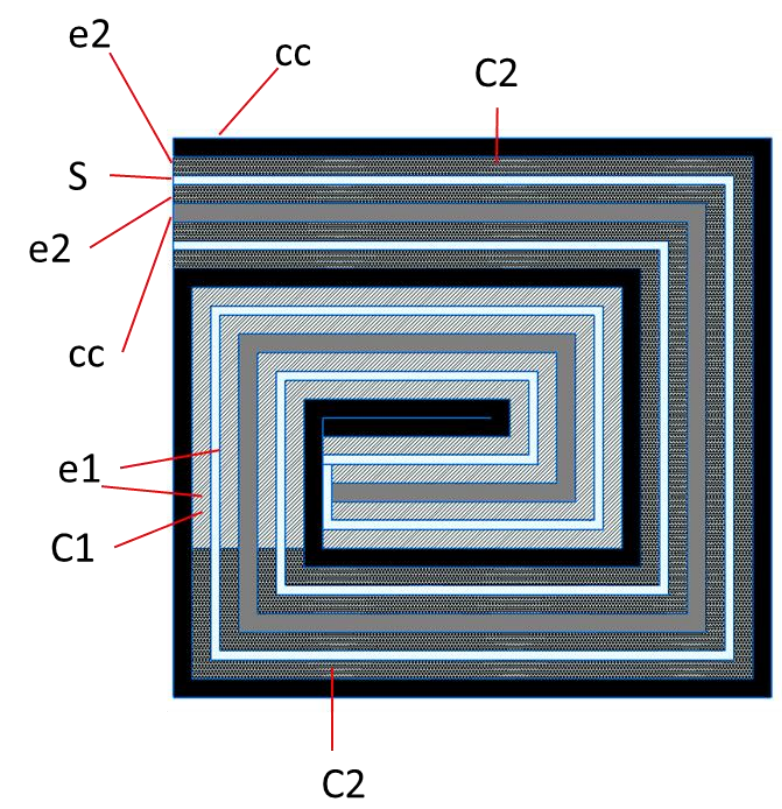

(c)

Fig.6 Diagrams of proposed forms of composite EDLC supercapacitors consisting of basic cell types (C1) and (C2), depending on the type of active electrode (e1) or (e2), respectively, and shared current collectors (cc): (a) Separate separator membranes for each cell (common separator S or two separators (S1) and (S2) for cell-types (C1) and (C2), respectively). (b) Meander-shaped separator (S). (c) Jelly-rolled type of composite cell. 

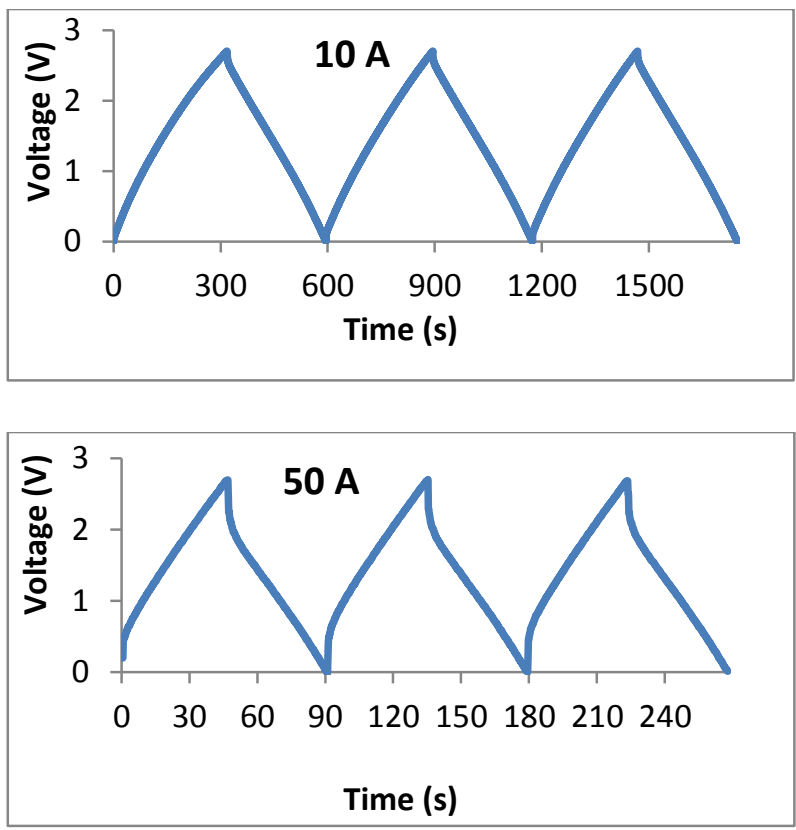

Fig.7 GCD data for the medium-size composite supercapacitor cell at $10 \mathrm{~A}$ and $50 \mathrm{~A}$. 

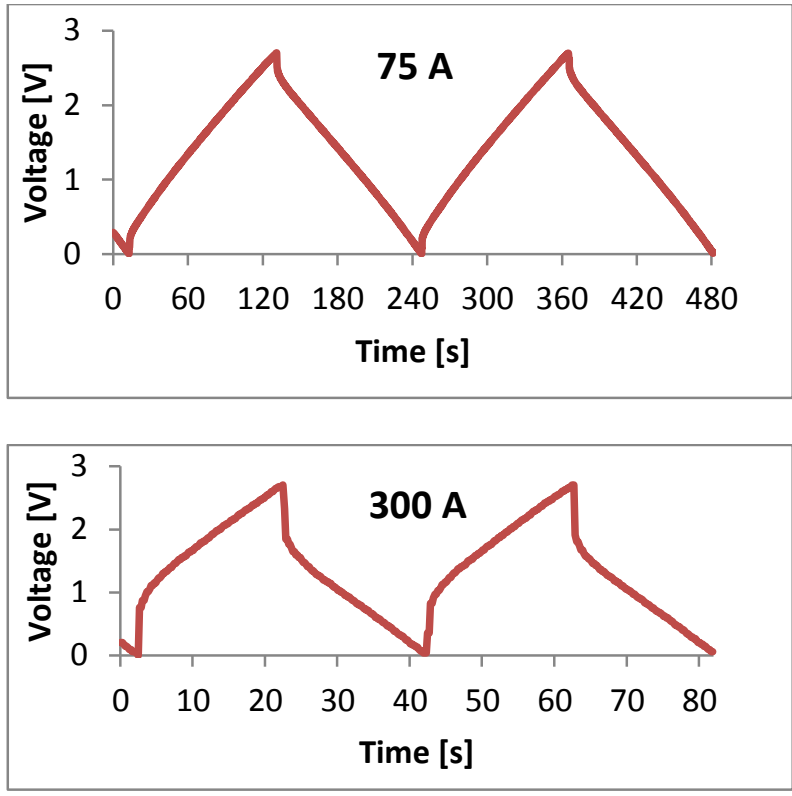

Fig.8 GCD data for the large-size composite supercapacitor cell at $75 \mathrm{~A}$ and $300 \mathrm{~A}$. 